\title{
Legislative Restrictions on Participation in Armed Conflicts in Latvia
}

\author{
Dr. iur., Professor Vitolds Zahars \\ Daugavpils University, Latvia \\ vitolds.zahars@inbox.lv \\ Ph.D., Vita Upeniece \\ Rìga Stradiňš University, Latvia \\ vita_up@yahoo.com
}

\begin{abstract}
Regulation of the Republic of Latvia ensures limitation of both illegal participation in armed conflicts and gaining unwanted military experience. The article analyses norms of the Criminal Law and the National Security Law which restrict the service in the armed forces of other countries and participation in the armed conflicts. These norms have been studied in connection with the norms of the Citizenship Law and the Law On Participation of Latvian National Armed Forces in International Operations. The purpose of the article is to propose the possible solutions to the identified problems, by analysing the stated regulation, in order to reduce the possible unintentional violation of the regulation by individuals.

The historical, analytical, systemic and teleological methods have been used in the preparation of the article.

Keywords: participation in the armed conflict, military service, Latvian citizenship, non-citizen.

\section{Introduction}

The number of armed conflicts in the world continues to grow [1], which raises the question of the quality of national regulation regarding the participation of Latvian citizens and non-citizens in armed conflicts of other countries and the service in the armed forces of other countries.

The amendments to the Criminal Law, which entered into force on 19 February 2015, introduced a prohibition of unlawful participation of Latvian citizens and
\end{abstract}


non-citizens in an armed conflict (taking place outside the territory of Latvia which is directed against territorial integrity or political independence of a state or is otherwise in contradiction with international law binding upon Latvia, violating laws and regulations or the international agreements binding upon Latvia) and on direct or indirect collection or transfer of financial resources acquired in any way, or other property to a party that is involved in an armed conflict (taking place outside the territory of Latvia and whose action is directed against territorial integrity or political independence of a state or is otherwise in contradiction with international law binding upon Latvia). These amendments to the Criminal Law also prohibit recruitment, training or sending of persons for unlawful participation in an armed conflict taking place outside the territory of Latvia. [2, Article 77. $\left.{ }^{1}, 77.2\right]$

Clause 2 of the first part of Article 24 of the Citizenship Law and Clause 4 of the first part of the Article 7 of the Law On the Status of those Former U.S.S.R. Citizens who do not have the Citizenship of Latvia or that of any Other State provide an opportunity for a Latvian citizen and non-citizen to serve in the armed forces of other countries after receiving the permission of the Cabinet of Ministers. This opportunity, according to the authors' opinion, may give the recipient of the permission of the Cabinet of Ministers a false impression that this permission also includes permission to participate in any armed conflict while serving in the armed forces of the concrete state and simultaneously excludes the possible liability provided for in the Criminal Law. It should be also mentioned that the refusal of a person, who has received the stated permission from the Cabinet of Ministers, to participate in an apparently unlawful armed conflict (according to the definition of the Criminal Law) may create grounds for the punishment for failure to observe the military discipline.

According to Article 3. ${ }^{1}$ of the National Security Law, Latvian citizens are prohibited from serving in the armed forces, internal security forces, military organisation, information service or security service, police (militia), or services of institution of justice of foreign states or other subjects of the international law or established in their territories, except when a Latvian citizen is serving in the service of the European Union (hereinafter - EU), the North Atlantic Treaty Organisation (hereinafter - NATO), a Member State of the EU, a Member State of the European Free Trade Association, a Member State of the North Atlantic Treaty Organisation, the Commonwealth of Australia, the Federative Republic of Brazil, or New Zealand, or in the service of such country with which Latvia has entered into an agreement regarding recognition of dual citizenship or when a Latvian citizen is serving in the service that is not recognised as voluntary in the country of his or her nationality with which the dual citizenship has occurred in accordance with the conditions of the Citizenship Law. According to the authors, this norm is only partially synchronised with the Citizenship Law, because the list of exceptions to this norm does not include the service in the armed forces of another country with the permission of the Cabinet of Ministers, which is provided for in Article 24, Paragraph 1, Clause 2 of the Citizenship Law. 
Meanwhile, Article 3. ${ }^{1}$ of the National Security Law prohibits non-citizens, without any exception and conditions, from serving in the armed forces, internal security forces, military organisation, information service or security service, police (militia), or services of institution of justice. But Clause 4 of Part 1 of Article 7 of the Law "On the Status of those Former U.S.S.R. Citizens who do not have the Citizenship of Latvia or that of any Other State" grants a non-citizen the right to obtain permission from the Cabinet of Ministers for the relevant service.

Theoretically, there is a possibility that a citizen or non-citizen, having received permission from the Cabinet of Ministers to service in the armed forces of another country, will start their service, mistakenly believing that this permission excludes the liability provided for in Article 95. of the Criminal Law (criminal liability for violation of Article 3. ${ }^{1}$ of the National Security Law).

\section{Unlawful Participation in Armed Conflict}

On February 19, 2015, amendments to the Criminal Law entered into force. These amendments prohibit Latvian citizens and non-citizens from unlawful participation in an armed conflict, direct or indirect collection or transfer of financial resources acquired in any way or other property to a party that is involved in an armed conflict and from recruitment, training or sending of a person for him or her to unlawfully participate in an armed conflict. [2, Article 4, 77., $\left.77^{2}, 77^{3}\right]$

The term "unlawful participation in an armed conflict taking place outside the territory of the Republic of Latvia" used in the above-mentioned regulation of the Criminal Law may be interpreted as follows:

By analysing these norms of the Criminal Law in connection with the regulations governing participation of persons in international missions or operations as part of the armed forces of the state. Reading Articles $77^{1}, 77^{2}$ and $77^{3}$ of the Criminal Law in connection with Article 2 of the Law on Participation of the Latvian National Armed Forces in International Operations, it can be concluded that lawful participation in the contingent of the Latvian National Armed Forces in an international operation means participation in the operations according to the Charter of the United Nations, or in accordance with the international agreements binding to Latvia and laws of Latvia, as well as a decision of the Saeima, of the Cabinet of Ministers or, in the case specifically provided for in the law, of the Minister for Defence on participation of the contingent of the Latvian National Armed Forces in international operations. [3]

Participation in an international mission or operation will be also legal if it is carried out by a person such as civilian expert. According to Article 12 of the Law on International Assistance, a civilian expert participates in international missions and operations based on a resolution, recommendation, or request of those international organisations which Latvia has entered into international agreements with, and also upon the invitation of a Member State the EU or the NATO. The Law on State Border 
Guard, the Law on Police and the Fire Safety and Fire-fighting Law offer similar regulations regarding participation of border guards, police officers and officials of the State Fire-fighting and Rescue Service with special service ranks in international operations and missions. $[4,5,6,7]$

However, by analysing these norms of the Criminal Law in connection with regulations that provide for obtaining permission from the Cabinet of Ministers to serve in the armed forces or military organisation of another country. According to Article 24, Paragraph one, Clause 2 of the Citizenship Law, Latvian citizenship may be revoked for a person if he or she is serving voluntarily in the armed forces or military organisation of another country, except where the person is serving in the armed forces or military organisation of a Member State of the EU, a Member State of the European Free Trade Association, a Member State of the NATO, the Commonwealth of Australia, the Federative Republic of Brazil, New Zealand or in the armed forces or military organisation of a country which Latvia has entered into an agreement with regarding recognition of dual citizenship, without permission from the Cabinet of Ministers, and in the case of revocation of Latvian citizenship the person does not become a stateless person. [8]

A person wishing to use the opportunity (provided by the Citizenship Law) to obtain the permission from the Cabinet of Ministers to serve in the armed forces or military organisation of another country not included in the list of exceptions of Article 24 of the Citizenship Law may be confused by the question whether the Citizenship Law and Article 77. ${ }^{1}$ of the Criminal Law are consistent with each other. That is, a person may rightly wonder whether the permission of the Cabinet of Ministers to serve in the armed forces or a military organisation of another country automatically includes permission to perform all military tasks, including participation in any international mission and operation.

A similar question may arise for a person who serves in the armed forces of the country/a military organisation which is included in the list of exceptions of Article 24 of the Citizenship Law (the service in the countries allowed by the Citizenship Law). This person may theoretically be in a situation where they will have to search an answer to the question whether the service in the armed forces, which is allowed by the national law, includes the right to participate in absolutely all missions and operations in these armed forces or military organisation. Also, whether such participation in an armed conflict always be recognized as legal within the meaning of the Criminal Law?

It should also be noted that military service is based on observance of military discipline, which according to Article 4 of the Law On Military Disciplinary Responsibility is explained as observance of procedures and instructions in the military service and in service in the National Guard. [9] In many countries there is a similar understanding of the issue of military discipline. Thus, for example, refusal of the Latvian citizen (who voluntarily serves in the armed forces of an EU member state or with the permission of the Cabinet of Ministers in another country's armed forces) to obey the order to 
participate in the mission (because they conclude that this mission is directed against territorial integrity or political independence of another state) may create legal basis for bringing such Latvian citizen to disciplinary responsibility in accordance with the laws and regulations of the country in whose armed forces they serve.

Although Article 24, Paragraph one, Clause 2 of the Citizenship Law and Article 77. ${ }^{1}$ of the Criminal Law seem to regulate the same issue, these norms should be distinguished, since each of them concerns the achievement of separate goals. If Article 24, Paragraph one, Clause 2 of the Citizenship Law defines cases when a person may be deprived of Latvian citizenship, the Criminal Law contains a prohibition on participation in armed conflicts outside the territory of Latvia if such participation occurs without observing laws, regulations or binding international agreements. Although the Cabinet of Ministers, when assessing the issue of allowing a Latvian citizen to serve in the armed forces of another country or military organisation, should take into account that a Latvian citizen will be obliged to perform all duties related to the military service, including participation in military missions; according to the authors' opinion, granting of such permission is most likely not to be considered as granting permission to participate in any armed conflict outside the territory of Latvia.

As mentioned above, the main purpose of the Citizenship Law is to define persons who are recognised as citizens of Latvia, while maintaining a set of citizens loyal to Latvia. Citizenship is considered a sensitive issue as it is essentially an expression of national sovereignty and identity. [10, 8] Article 24, Paragraph one, Clause 2 of the Citizenship Law provides prohibition to the service in the armed forces or military organisations of other countries not included in the list of exceptions of the Clause 2 Part 1 of Article 24. As the punishment for failure to comply with such obligation, the Article provides deprivation of citizenship. But in the case of revocation of Latvian citizenship, the person should not become a stateless person in compliance with the Convention on the Reduction of Statelessness. [11] Thus, if a Latvian citizen who does not have a citizenship of another state violates this regulation, they will most likely not lose Latvian citizenship.

In addition, the Citizenship Law does not oblige a Latvian citizen to obtain the permission from the Cabinet of Ministers to serve in the armed forces or a military organisation of an EU member state, a member state of the European Free Trade Association, a member state of the NATO, the Commonwealth of Australia, the Federative Republic of Brazil, New Zealand or in the armed forces or military organisation of a country with which Latvia has entered into an agreement regarding recognition of dual citizenship.

Neverthless, the aim of Article 77. ${ }^{1}$ of the Criminal Law is to prohibit Latvian citizens from participating in an armed conflict taking place outside the territory of Latvia which is directed against territorial integrity or political independence of a state or is otherwise in contradiction with international law binding upon Latvia.

Thus, although the mentioned regulation of both laws contains a reference to service in the armed formations of other countries, the main aims of the two laws are different. 
When deciding whether to allow the service in another country's armed forces or military organisation, in the current fast changing world, it would be difficult or impossible for the Cabinet of Ministers to predict in which future armed conflicts exactly this country or military organisation may be involved. It should be noted that the Citizenship Law contains provision on deprivation of citizenship in cases where a person served in the armed forces of another state without the permission of the Cabinet of Ministers since the law has entered into force, that is, since 25 August 1994. On the other hand, prohibition of unlawful participation in an armed conflict taking place outside the territory of Latvia, which is included in Article 77. ${ }^{1}$ of the Criminal Law, entered into force on 19 February 2015 - at a time when participation of volunteers in armed conflicts taking peace in other countries became one of the problems in the field of international security. [12]

Similarly to the Citizenship Law, Article 7, Paragraph 1, Clause 4 of the Law "On the Status of those Former U.S.S.R. Citizens who do not have the Citizenship of Latvia or that of any Other State" provides that the non-citizen status of a person shall be revoked if they serve in the armed forces, internal security force, security service, police (militia) of any foreign country, or is in service of judicial institutions without permission of the Cabinet of Ministers. Unlike the Citizenship Law, this Law does not contain a list of countries in which non-citizens have the right to serve without the permission of the Cabinet of Ministers. [13] Therefore, non-citizens who receive the permission from the Cabinet of Ministers to serve in the armed forces of another country or another organisation may also face the mentioned issues.

Consequently, a person who decides to serve in the armed forces of another country or organisation should consider all risks connected with the fulfilment of such decision.

\section{Service in the Armed Forces of Foreign Countries}

Amendments to the National Security Law and the mentioned amendments to the Criminal Law, which provide additional rules limiting acquisition of military experience, entered into force on January 1, 2017. The National Security Law was supplemented with Article 3. ${ }^{1}$ which prohibits a Latvian citizen to serve in the armed forces, internal security forces, military organisation, information service or security service, police (militia), or services of institution of justice of foreign country or other subjects of the international law or established in their territories, except the case when:

1) a Latvian citizen is serving in the service of the EU, the NATO, a Member State of the EU, a Member State of the European Free Trade Association, a Member State of the NATO, the Commonwealth of Australia, the Federative Republic of Brazil, or New Zealand, or in the service of such country with which Latvia has entered into an agreement regarding recognition of dual citizenship;

2) a Latvian citizen is serving in the service that is not recognised as voluntary in the country of their nationality with which the dual citizenship has occurred in accordance with the conditions of the Citizenship Law. [14] 
Thus, the mentioned norm prohibits such service which may be related to a special training of military nature with the use of service weapons. In the authors' opinion, this norm is partially synchronised with the Citizenship Law. It does not prohibit the service in those countries where the permission of the Cabinet of Ministers is not required in accordance with Paragraph 2 of the first part of Article 24 of the Citizenship Law. The norm of the National Security Law, observing the obligation arising from the institute of citizenship to be loyal to the country of his or her citizenship and to protect its freedom and independence, does not prohibit the citizen of Latvia (who has established a dual citizenship in accordance with the Citizenship Law regulation) to perform a compulsory military service or service of general military duty in the country of the second citizenship. [15] Simultaneously, the list of exceptions to this norm does not include service in the armed forces of another state with the permission of the Cabinet of Ministers.

In addition, according to Article $3{ }^{1}$ of the National Security Law, non-citizens are prohibited from serving in the service (serving in the armed forces, internal security forces, military organisation, information service or security service, police (militia), or services of institution of justice) of a foreign country without any exceptions or conditions.

Obedience of the mentioned requirements of the National Security Law is ensured by amendments to the Criminal Law, which entered into force on January 12, 2017. According to Article 95. ${ }^{1}$ of the Criminal Law, criminal liability arises for violation of the of prohibition of requirements of laws and regulations to serve in the armed forces, internal security forces, military organisation, intelligence service or security service, police (militia), or services of institution of justice of foreign country or other subjects of the international law or established in their territories. [2]

Moreover, norms of the Citizenship Law and the Law On the Status of those Former U.S.S.R. Citizens who do not have the Citizenship of Latvia or that of any Other State, which requires permission from the Cabinet of Ministers for the service, seem to contradict with the strict restrictions of Article $3{ }^{1}$ of the National Security Law. Theoretically, there is a possibility that a person, having received the permission of the Cabinet of Ministers mentioned in the Citizenship Law or in the Law On the Status of those Former U.S.S.R. Citizens who do not have the Citizenship of Latvia or that of any Other State, will start and perform this service being convinced that this permission of the Cabinet of Ministers completely excludes liability provided for in Article 95. ${ }^{1}$ of the Criminal Law.

The authors provide two possible solutions to prevent such situations.

The first one would be to amend Article 24 of the Citizenship Law and Article 7 of the Law On the Status of those Former U.S.S.R. Citizens who do not have the Citizenship of Latvia or that of any Other State, and to exclude the possibility to serve with the permission of the Cabinet of Ministers in the armed forces, internal security forces, military organisation, intelligence service or security service, police (militia), or services of institution of justice of foreign countries or other subjects of the international law or established 
in their territories. The wording of the amendments may be as follows: in the Citizenship Law - "to exclude Clause 2 of the first part of Article 24"; in the Law On the Status of those Former U.S.S.R. Citizens who do not have the Citizenship of Latvia or that of any Other State - "to exclude Clause 4 of the first part of Article 7".

Another proposal it not to amend the Citizenship Law and the Law On the Status of those Former U.S.S.R. Citizens who do not have the Citizenship of Latvia or that of any Other State. These two laws are relatively rarely amended. Since its entry into force on August 25, 1994, the Citizenship Law has been amended only 4 times, and the Law On the Status of those Former U.S.S.R. Citizens who do not have the Citizenship of Latvia or that of any Other State (since its entry into force on May 9, 1995) - 7 times. According to the information report of the Ministry of Justice, "Proposals for reducing the number of amendments to regulatory enactments" adopted at the Cabinet of Ministers on 26 August 2014, despite administrative and financial expenses created by the often drafting of regulatory enactments or their amendments and despite the creation of negative impact on the public's attitude towards such often amended regulatory enactments, the number of both laws and regulations tends to increase. The Ministry of Justice has concluded in this information report that certain regulatory enactments are amended several times even within one year. [16] Thus, taking into account the issue of amendments to regulatory enactments in general, relatively rare amendments to certain laws can confirm either the high quality of the legal framework of them and the full compliance with the purpose of their issuance - the compliance with all life situations covered by them, or the refusal of the legislator to "open" for amendments such laws which regulate sensitive issues in the society.

The Citizenship Law and the Law on the Status of those Former U.S.S.R. Citizens who do not have the Citizenship of Latvia or that of any Other State are amended relatively rarely. Therefore, as a second solution to the mentioned problem, may be the advice to the Cabinet of Ministers to remember the regulation of the National Security Law and the Criminal Law and to refuse to issue a permit to serve in another country's armed forces or military organisation if a request for such permit is received.

\section{Conclusions}

To eliminate the identified shortcomings of synchronisation between Article 24 of the Citizenship Law, Article 7 of the Law on the Status of those Former U.S.S.R. Citizens who do not have the Citizenship of Latvia or that of any Other State and Article 3. ${ }^{1}$ of the National Security Law, the following solutions are possible:

1. To make amendments to Article 24 of the Citizenship Law and Article 7 of the Law On the Status of those Former U.S.S.R. Citizens who do not have the Citizenship of Latvia or that of any Other State, and to exclude the possibility of receiving a permission from the Cabinet of Ministers for the service in another country. The wording of the amendments may be as follows: in 
Vitolds Zahars, Vita Upeniece. Legislative Restrictions

on Participation in Armed Conflicts in Latvia

the Citizenship Law - "to exclude Clause 2 of the first part of Article 24"; in the Law On the Status of those Former U.S.S.R. Citizens who do not have the Citizenship of Latvia or that of any Other State - "to exclude Clause 4 of the first part of Article 7".

2. Not to amend the Citizenship Law and the Law On the Status of those Former U.S.S.R. Citizens who do not have the Citizenship of Latvia or that of any Other State. To recommend the Cabinet of Ministers to remember the regulation of the National Security Law and the Criminal Law and to refuse issuing a permit for service in another country's armed forces or military organisation if a request for such permission is received.

\section{Bibliography}

1. Sarunas par pasauli 2030. gadā: NBS komandieris generālleitnants L. Kalniṇš (Eng. Talks about the world in 2030: NAF Commander Lieutenant General L. Kalniṇš). (23.01.2021.) Sargs.lv. https://www.sargs.lv/lv/viedoklis/2021-01-23/sarunas-par-pasauli-2030-gada-nbs-komandierisgeneralleitnants-l-kalnins.

2. Latvijas Republikas likums: Krimināllikums (Eng. Law of the Republic of Latvia: Criminal Law), Latvijas Vēstnesis, 199/200, 08.07.1998. https://likumi.lv/ta/id/88966-kriminallikums.

3. Latvijas Republikas likums: Latvijas Nacionālo bruṇoto spēku piedalīšanās starptautiskajās operācijās (Eng. Law of the Republic of Latvia: Participation of the Latvian National Armed Forces in International Operations), Latvijas Vēstnesis, 30, 25.02.1995. https://likumi.lv/ta/ id/34028-latvijas-nacionalo-brunoto-speku-piedalisanas-starptautiskajas-operacijas.

4. Latvijas Republikas likums: Starptautiskās palīdzības likums (Eng. Law of the Republic of Latvia: Law on International Assistance), Latvijas Vēstnesis, 74, 14.05.2008. https://likumi.lv/ ta/id/175254-starptautiskas-palidzibas-likums.

5. Latvijas Republikas likums: Par policiju (Eng. Law of the Republic of Latvia: On the Police), Latvijas Republikas Augstākās Padomes un Valdības Ziṇotājs, 31/32, 15.08.1991. https://likumi. lv/ta/id/67957-par-policiju.

6. Latvijas Republikas likums: Ugunsdrošības un ugunsdzēsības likums (Eng. Law of the Republic of Latvia: Law on Fire Safety and Firefighting), Vēstnesis, 165, 13.11.2002. https://likumi.lv/ta/ id/68293-ugunsdrosibas-un-ugunsdzesibas-likums.

7. Latvijas Republikas likums: Valsts robežsardzes likums (Eng. Law of the Republic of Latvia: Law on the State Border Guard), Latvijas Vēstnesis, 223, 17.11.2020. https://likumi.lv/ta/id/318741valsts-robezsardzes-likums.

8. Latvijas Republikas likums: Pilsonības likums (Eng. Law of the Republic of Latvia: Citizenship Law), Latvijas Vēstnesis, 93, 11.08.1994. https:/likumi.lv/ta/id/57512-pilsonibas-likums.

9. Latvijas Republikas Likums: Militārās disciplināratbildības likums (Eng. Law of the Republic of Latvia: Law on Military Disciplinary Liability), Latvijas Vēstnesis. 223, 17.11.2020. https:// likumi.lv/ta/id/318749-militaras-disciplinaratbildibas-likums.

10. Nationality and Statelessness: A Handbook for Parliamentarians. Handbook for Parliamentarians. UNHCR and IPU. 2005. 
Vitolds Zahars, Vita Upeniece. Legislative Restrictions

on Participation in Armed Conflicts in Latvia

11. Starptautisks dokuments: Konvencija par bezvalstniecības samazināšanu (Eng. International document: Convention on the Reduction of Statelessness), Latvijas Vēstnesis, 135, 30.08.2011. https://ikumi.lv/ta/lv/starptautiskie-ligumi/id/700.

12. Likumprojekta "Grozījumi Krimināllikumā” sākotnējās ietekmes novērtējuma ziṇojums (anotācija) (Eng. Preliminary Impact Assessment Report of the Draft Law "Amendments to the Criminal Law" (annotation)), 13.01.2015. http://titania.saeima.lv/LIVS12/SaeimaLIVS12. nsf/0/47765D4DD0FD4736C2257DD3002AF17A?OpenDocument.

13. Latvijas Republikas likums: Par to bijušās PSRS pilsoṇu statusu, kuriem nav Latvijas vai citas valsts pilsonibas (Eng. Law of the Republic of Latvia: On the Status of those Former Citizens of the USSR Who Do Not Have the Citizenship of Latvia or Another State, Latvijas Vēstnesis, 63, 25.04.1995. https://likumi.lv/ta/id/77481-par-to-bijusas-psrs-pilsonu-statusu-kuriem-navlatvijas-vai-citas-valsts-pilsonibas.

14. Latvijas Republikas likums: Nacionālās drošîbas likums (Eng. Law of the Republic of Latvia: National Security Law): Latvijas Republikas likums, Latvijas Vēstnesis, 473/476, 25.04.1995. https://likumi.lv/ta/id/77481-par-to-bijusas-psrs-pilsonu-statusu-kuriem-nav-latvijas-vai-citasvalsts-pilsonibas.

15. Likumprojekta "Grozījumi Nacionālās drošības likumā” sākotnējās ietekmes novērtējuma ziṇojums (anotācija) (Eng. Preliminary Impact Assessment Report of the Draft Law "Amendments to the National Security Law" (annotation)). 09.08.2016. http://titania.saeima.lv/LIVS12/ SaeimaLIVS12.nsf/0/77F50F0F4FEC167FC22580110040293F?OpenDocument.

16. Tieslietu ministrijas izstrādātais informatīvais ziņojums "Priekšlikumi ārējo normatīvo aktu grozijumu skaita samazināšanai” (Eng. Informative report prepared by the Ministry of Justice "Proposals for reducing the number of amendments to external regulatory enactments"), 26.08.2014. http://tap.mk.gov.lv/lv/mk/tap/?pid=40306253\& mode=mk\&date=2014-08-26. 